\title{
Factor Affecting Adoption of Ubiquitous Computing in Knowledge Sharing: Comparison between Local and Foreign Employees in Private University Malaysia
}

\author{
Yuen Yee Yen ${ }^{1}$, Lew Sook Ling ${ }^{1} \&$ Seethaletchumy A/P Thambiah ${ }^{1}$ \\ ${ }^{1}$ Multimedia University. Jalan Ayer Keroh Lama, Melaka, Malaysia \\ Correspondence: Yuen Yee Yen, Faculty of Business, Multimedia University, Jalan Ayer Keroh Lama, 75450 \\ Melaka, Malaysia. E-mail: yyyuen@mmu.edu.my
}

Received: September 10, 2014

Accepted: October 8, $2014 \quad$ Online Published: December 20, 2014

doi:10.5539/ijbm.v10n1p161

URL: http://dx.doi.org/10.5539/ijbm.v10n1p161

\begin{abstract}
This study aims to propose a research framework that could be used to examine key factors affecting adoption of ubiquitous computing devices in knowledge sharing from the perspectives of foreign and local employees in private universities Malaysia. This research provides recommendations to the management and educational practitioners to promote and enhance foreign and local employees' adoption of ubiquitous computing devices in knowledge sharing in private universities Malaysia. Five hundred questionnaires were distributed to foreign and local employees who are currently working in top private universities in Malaysia. The finding of this study shows that collaborative organisational culture and help facility availability are two important factors that affect adoption of ubiquitous computing devices in knowledge sharing from the perspectives of both foreign and local employees in private universities Malaysia. Strategic future planning positively influences local employees' adoption of ubiquitous computing devices in knowledge sharing but it does not significantly affect foreign employees' adoption of ubiquitous computing devices in knowledge sharing.
\end{abstract}

Keywords: Ubiquitous computing devices, knowledge sharing, framework

\section{Introduction}

Knowledge sharing in higher learning institution is essential for Malaysia to become a developed, high-income and knowledgeable country by the year 2020. Knowledge is a key asset for universities to succeed in the competitive economies (Cheng, 2009; Yang, 2008). Effective knowledge sharing by utilising ubiquitous computing devices among foreign and local employees is imperative to ensure that private universities Malaysia are able to compete with universities from all over the world in the era of globalisation.

Ubiquitous computing is categorised by a profusion of interacted computational devices engrained within daily working and living environments (Chiou et al., 2010). Ubiquitous computing expands the scope of knowledge sharing and user interaction from a limited interaction with specific mobile device to a broad interaction with the environment as a whole for knowledge acquisition and enhancement. As foreseen by Weiser (1991), ubiquitous computing will assimilate computational mobile and wireless devices into human lives in the next decades, complementing their daily interaction with surrounding people.

\subsection{Research Background}

Ubiquitous computing has paved way to knowledge sharing by using mobile and wireless technologies (Huang et al., 2010). Effective knowledge sharing in education sector has been enhanced by the portability and ability of mobile and wireless devices to support instantaneous communication and quick learning processes through interacting with peers, fast accessing to teaching and learning resources and transforming raw data into useful information (Huang et al., 2010). Mobile devices and wireless Internet technology enable students and working adults to learn by acquiring an assortment of digital content at anytime from anywhere in the world (Hsieh et al., 2011). It has undoubtedly enhanced the accessibility and easiness of the learning and knowledge sharing process in education.

Ubiquitous computing allows learners to be self-directed and student centred (Hsieh et al., 2011) by utilizing information they obtain from schools and the Internet to solve problems in a timely manner (Chiou et al., 2010). 
Learner can also have a lively and immediate interaction and knowledge sharing with experts, instructors and peers (Hsieh et al., 2011). Moreover, collaborative networks such as virtual laboratories can be created to enable individuals from different locations to work and learn together (Camarinha-Matos \&Anesh, 2005). Liu et al. (2009) states that ubiquitous computing supports effective learning and knowledge transfer process, which is characterised as seamlessness, provides greater flexibility and convenience to the learners compared to traditional classrooms.

On top of that, the accelerated global adoption of smart phones has also widen the adoption of social web-based applications such as YouTube, Facebook, Wikipedia, which will tremendously enhance the knowledge sharing and learning and teaching practices (Multisilta \& Milrad, 2009). As learners can share experiences and learn new knowledge from a broader universe of user-generated content, beyond the textbooks in traditional classroom, a comprehensive research, which examines key factors affecting the adoption of ubiquitous computing in knowledge sharing in higher learning institution, will become more and more imperative than before.

Unfortunately, at present, there is insufficient research framework that examines key factors affecting the adoption of ubiquitous computing devices such as a PDA, tablet computers or smart phones in knowledge sharing from the perspectives of foreign and local employees. Local and worldwide researchers seem to have overlooked the adoption of ubiquitous computing devices among foreign and local employees in private learning institutions (Finestone \& Snyman, 2005; Mustapha \& Abdullah, 2005). Most of the previous studies constrained themselves into examining knowledge sharing behaviours of local employees (Finestone \& Snyman, 2005; Voel $\&$ Han, 2005). For instance, Finestone and Snyman (2005) concentrated on studying the negative factors that prohibited knowledge sharing in South Africa. Voel and Han (2005) concentrated on comparing the knowledge sharing of Chinese and American citizens without conducting detailed analysis on key factors that influences the actual adoption of ubiquitous computing devices in knowledge sharing involvements of citizens from both countries. This study is therefore conducted to fill the research gaps of previous literature.

The objective of this study is to propose a research framework that could be used to examine key factors affecting foreign and local employees' adoption of ubiquitous computing devices in knowledge sharing in private universities Malaysia.

This research has important implications for research and practice. It assists the educational practitioners and local governments to understand the actual perception and attitude of local and foreign employees in private universities Malaysia towards utilising ubiquitous computing devices in knowledge sharing. It also provides constructive recommendations to the management and educational practitioners to promote ubiquitous computing devices to enhance knowledge sharing involvement of foreign and local employees in private universities Malaysia. Based on the actual needs and perceptions of foreign and local employees, practitioners could design the knowledge management policies in their universities to create conducive organisational collaborative organisational culture for employees to share knowledge from the perspectives of themselves. In addition, this study will also enrich the current literature, which is seemingly lack of established framework for studying factors affecting the adoption of ubiquitous computing devices from the perspectives of foreign and local employees in private universities. Meticulous research instrument and framework used in this study could also become a good reference for future research in similar area.

\section{Literature Review}

\subsection{Adoption of Ubiquitous Computing in Knowledge Sharing}

Knowledge sharing behaviour measures an employee's involvement in acquiring, accessing, disseminating and exchanging knowledge and intellectual properties with other employees in an organization (Montana, 2000). The adoption of ubiquitous computing in knowledge sharing among foreign and local employees in private university is important to the sustainability of the learning institutions (Cheng, 2009). Effective knowledge sharing by utilising the latest ubiquitous technology will improve the productivity and efficiency of the organization by effectively transferring the knowledge and technological skills of an experienced foreign employee to a local employee (Yang, 2008).

Knowledge sharing is an important component of knowledge management in educational sector, which disseminate information about how to manage people, processes, and technologies in the organisations to staff through formal and informal communication (Petrides \& Nodine, 2003). There are two types of knowledge to be shared using ubiquitous computing technology in higher education institutions, academic knowledge and organizational knowledge. Academic knowledge is the formal knowledge about the teaching and learning activities in a university, organizational knowledge refers to knowledge of the overall strength and weaknesses, market share critical organizational success factors of the particular university (Coukos-Semmel, 2003). It is 
strongly believed that effective knowledge sharing among employees can strengthen educational administration, which in turn enhances teaching and learning in the university (Petrides \& Guiney, 2002). Knowledge can be shared with the help of ubiquitous computing between two or more employees who serve as knowledge seeker and knowledge provider (Petrides \& Guiney, 2002). Knowledge seeker is the employee in the university who wishes to enhance their knowledge and knowledge provider is the academic and administrative employee in the university who prepares the learning content with the support of ubiquitous computing technology (Petrides \& Guiney, 2002).

User adoption of ubiquitous computing devices in knowledge sharing among local and foreign employees in private universities can be influenced by the following factors:

\subsection{Individualism}

The first factor, individualism, refers to the situation in which the needs of groups are more important than personal benefits (Wagner, 1995). Employees with high individualism prefer to stay alone and dislike knowledge exchange in the organization (Bates, 1995). They prefer to hoard knowledge and are reluctant to share and exchange knowledge using the latest computing technology (Nonaka \& Takeuchi, 1995).

Bhagat et al. (2002) classified individualism as the major distinguishing characteristic in the way that different societies process and share information. Triandis (1998) defined individualism as a group of loosely linked individuals in the society who has independent and unique preferences and needs compared to the majority of the society who perceive themselves as belonging to the organizations that they serves. A number of previous literature (Bhagat et al., 2002; Triandis, 1998) highlighted that individualism strongly influences employees' intentions to share knowledge without incorporating the use of ubiquitous computing in knowledge sharing and including a detailed comparison between local and foreign staff. This study is therefore carried out to address these research gaps. The following hypothesis is formed to examine the influence of individualism on local and foreign employees' adoption of ubiquitous computing devices for knowledge sharing in private universities Malaysia.

H1: Individualism affects local and foreign employees' adoption of ubiquitous computing devices in knowledge sharing in private universities Malaysia.

\subsection{Strategic Future Planning}

The second variable, strategic future planning has been identified as employees' willingness to adopt ubiquitous computing devices to share their knowledge and expertise for future career development (Gupta \& Govindarajan, 2000; Szulanski, 1996). Employees who have meticulous and attainable future planning would be more likely to explore and share knowledge with other employees in the organization (Alavi \& Leidner, 2001).

Previous studies on strategic future planning were limited only to novice workers and experienced workers. For example, Zimmerman and Kitsantas (1999) indicated that experienced workers used technique-oriented strategies to establish specific long-term process goals but novice workers often do not have a habit to plan for future (Kitsantas \& Zimmerman, 2002). Another studies, Clearly and Zimmerman (2001) and Locke and Latham (2002) discovered that experienced workers tend to have significantly higher self-efficacy and they prefer to set neither too high nor too low standard to measure their job performances. Experienced workers were more likely to learn new knowledge voluntarily and are more adaptive than novices in adopting new technology in learning (Kitsantas \& Zimmerman, 2002). Previous literature of strategic future planning had three major gaps. First, it did not relate strategic knowledge planning with the adoption of ubiquitous computing. Second, it did not correlate strategic knowledge planning with knowledge sharing behaviours. Third, it did not make a comparison of strategic future planning among foreign and local employees. This study is therefore carried out to address these three research gaps. The following hypothesis is formed to test the influence of strategic future planning on local and foreign employees' adoption of ubiquitous computing devices for knowledge sharing in private universities Malaysia.

H2: Strategic future planning affects local and foreign employees' adoption of ubiquitous computing devices in knowledge sharing in private universities Malaysia.

\subsection{Collaborative Organisational Culture}

The next factor, collaborative organisational culture, measures the availability of a pleasant working environment that fully supports employees' adoption of ubiquitous computing devices in knowledge sharing. The biggest challenge of knowledge sharing is insufficient commitment and support (Kelloway \& Barling, 2000). Conducive organisational collaborative organisational culture need to be created to encourage employees who are more familiar with current working procedure to share knowledge with new colleagues (Flaherty \& Perk, 2000). 
Previous research (Lopez et al., 2004; Kulkarni, Ravindran \& Freeze, 2007) highlighted the importance of a collaborative organizational culture in enabling the successful implementation of knowledge sharing and transfer in the organisation. Alavi, Kayworth and Leidner (2005) further elaborate that collaborative organisational culture traits such as innovativeness, trust and autonomy lead to effective knowledge sharing in an organisation. However, all the past literature did not incorporate the adoption of ubiquitous computing in knowledge sharing among local and foreign staff in private universities. In order to address these research gaps, the following hypothesis is formed to examine the influence of collaborative organisational culture on local and foreign employees' adoption of ubiquitous computing devices for knowledge sharing in private universities Malaysia.

H3: Collaborative organisational culture affects local and foreign employees' adoption of ubiquitous computing devices in knowledge sharing in private universities Malaysia.

\subsection{Help Facility Availability}

Help facility availability is the next factor which might have a positive influence on foreign and local employees' adoption of ubiquitous computing devices in knowledge sharing. Help facility availability refers to the readiness of supplementary tools such as written documents, service centres and technological infrastructure in supporting of the use of ubiquitous computing devices for knowledge acquisition in an organization (Ajzen \& Driver, 1992; Cheng, 2009; Reige, 2005).

Since ubiquitous computing is impersonal, previous literature discovered that customers often are more unaware about the services and applications in support of knowledge sharing and how ubiquitous technologies can enhance knowledge sharing experiences in the workplace (Liu et al., 2005; Nijite \& Parsa, 2005). They tend to expect immediate assistance from service developer to assist them to overcome service uncertainty and resolve all the technical difficulties that they might be facing while using ubiquitous computing devices (Liu et al., 2005; Nijite \& Parsa, 2005). Users are not willing to waste time and cognitive effort reading the privacy policy and wish to get immediate assistance from the expert to enhance their usage experience (Liu et al., 2005; Nijite \& Parsa, 2005). However, the past literature did not measure the availability of help desk and facility in the adoption of ubiquitous computing for knowledge sharing among local and foreign staff in private universities. In order to address these research gaps, the following hypothesis is formed to examine the influence of help facility in the adoption of ubiquitous computing devices for knowledge sharing among local and foreign employees in private universities Malaysia.

\section{H4: Help facility availability affects the adoption of ubiquitous computing devices in local and foreign} employees' knowledge sharing in private universities Malaysia.

Figure 1 shows the research framework of this study. This study has 1 dependent variable (adoption of ubiquitous computing devices in knowledge sharing) and 4 independent variables (individualism, strategic future planning, collaborative organisational culture and help facility availability). 


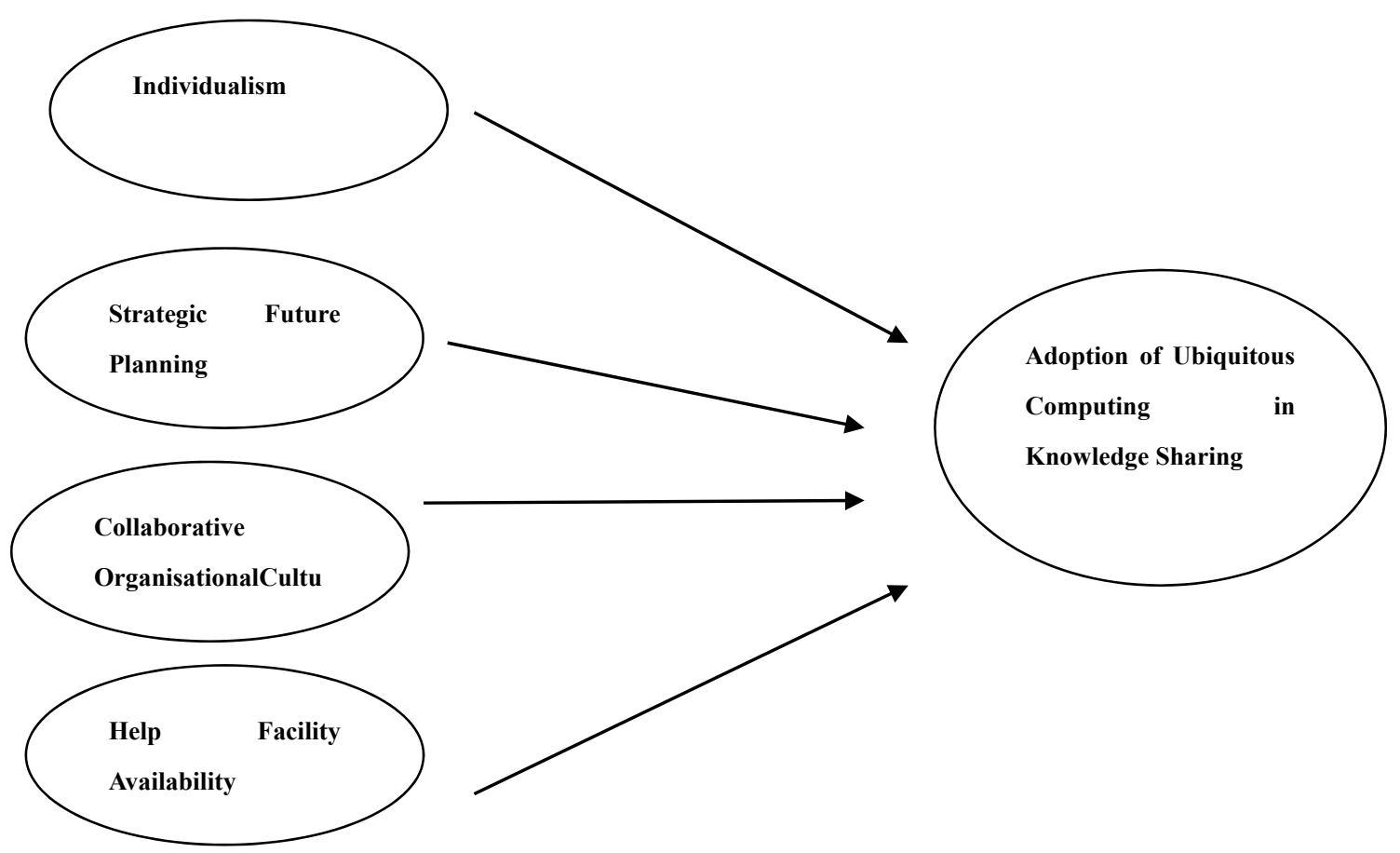

Figure 1. Research framework

\section{Research Methodology}

The present study is a quantitative study. A questionnaire is designed based on the research framework, trailed in a pilot study, and finally distributed to a sample of 500 foreign and local employees. Random sampling method is applied to select a sample of 500 respondents from 5 top private universities listed in the SETARA Rating System for Malaysian Higher Education System. The questions are developed based on literature reviews and tested for reliability and validity. The questionnaire consists 25 items measuring independent variables, 6 items related to individualism, 6 items related to strategic future planning, 7 items related to collaborative organisational culture and 6 items related to help facility availability. In addition, there are also 5 items measuring user adoption of ubiquitous computing in knowledge sharing. Each respondent was given thirty minutes to answer the questionnaire. Souvenirs such as pens and key chains were given to encourage respondents to answer the questionnaires. Out of 500 distributed questionnaires, 288 valid questionnaires were collected and used in further analysis of this study. The questionnaire data was analyzed using the Statistical Package for the Social Sciences (SPSS) statistical software version 21.0. Best practices are incorporated into the design of the survey questionnaire to reduce response biases in this research (Sekaran, 2003). All questions asked in the questionnaires are kept simple and direct to refrain from unnecessary errors such as leading questions, double negatives, jargon or overly technical concepts (Sekaran, 2003). The questionnaire is evaluated by knowledge management experts to ensure the items and measurements used for the constructs are appropriate prior to the distribution of questionnaire. Hence, content validity is confirmed before running statistical analyses to confirm the data reliability (Hair et al., 2010).

\section{Results}

Forty-eight percent of the respondents of this study are males and fifty-two percent of the respondents are females as shown in Table 1. Eighty-five percent of the respondents are Malaysian citizens and fourteen percent are foreign employees that work in private universities Malaysia. Permanent employees comprises of sixty-eight percent while the remaining is contract employees. 
Table 1. Demographics

\begin{tabular}{llll}
\hline Demographics & & Frequency & Percentage (\%) \\
\hline Gender & Female & 150 & 47.9 \\
& Male & 138 & 52.1 \\
Category & Local Employees & 247 & 85.8 \\
& Foreign & 41 & 14.2 \\
\multirow{4}{*}{ Status } & Employees & & \\
& Permanent & 196 & 68.1 \\
& Contract & 92 & 31.9 \\
\hline
\end{tabular}

Construct validity of this study is confirmed by using a principal axis factoring as indicated in Tables 2 . The Kaiser-Meyer-Olkin measures of sampling adequacy (MSA) for items measuring independent and dependent variables are found to be 0.830 , exceeding the acceptable cut-off point of 0.50 (Hair et al., 2010), indicating that the data is deemed appropriate to apply factor analysis. Thirty items in the questionnaire can be fitted into five factors with eigenvalues greater than 1.0. The five factors are individualism, strategic future planning, collaborative organisational culture, help facility availability and adoption of ubiquitous computing in knowledge sharing, which explain $25.32 \%$ of the total variance. All factor loadings for the research instrument are greater than 0.4 (Tables 2), accentuating the construct validity of the research instrument (Hair et al., 2010).

Table 2. Factor analysis

\begin{tabular}{|c|c|c|c|c|c|}
\hline \multirow[t]{2}{*}{ Items } & \multicolumn{5}{|c|}{ Factor } \\
\hline & Individualism & $\begin{array}{l}\text { Strategic } \\
\text { Future } \\
\text { Planning }\end{array}$ & $\begin{array}{l}\text { Collaborative } \\
\text { Organisational } \\
\text { Culture } \\
\end{array}$ & $\begin{array}{l}\text { Help Facility } \\
\text { Availability }\end{array}$ & $\begin{array}{l}\text { Adoption of Ubiquitous } \\
\text { Computing in Knowledge } \\
\text { Sharing }\end{array}$ \\
\hline Enjoy being unique and different & .835 & & & & \\
\hline Important to act as independent person. & .723 & & & & \\
\hline $\begin{array}{l}\text { Put self-interest on top of the benefit of } \\
\text { my group. }\end{array}$ & .667 & & & & \\
\hline Responsibility for own actions. & .814 & & & & \\
\hline Polite when interacting with superiors. & .646 & & & & \\
\hline $\begin{array}{l}\text { Prefer to make decision alone without } \\
\text { discussing problem with colleagues. }\end{array}$ & .551 & & & & \\
\hline Emphasizes long range planning. & & .744 & & & \\
\hline $\begin{array}{l}\text { Motivates employee to initiate changes in } \\
\text { company. }\end{array}$ & & .688 & & & \\
\hline Emphasizes future opportunities. & & .653 & & & \\
\hline $\begin{array}{l}\text { Motivates employee by providing } \\
\text { training, seminar and workshop on } \\
\text { ubiquitous computing. }\end{array}$ & & .634 & & & \\
\hline $\begin{array}{l}\text { Recognizes and rewards creativity in } \\
\text { knowledge acquisition using ubiquitous } \\
\text { computing. }\end{array}$ & & .592 & & & \\
\hline Emphasizes innovation & & .567 & & & \\
\hline $\begin{array}{l}\text { Boss encourages to discuss work-related } \\
\text { problems with colleagues }\end{array}$ & & & .830 & & \\
\hline $\begin{array}{l}\text { Boss gives rewards when sharing } \\
\text { knowledge }\end{array}$ & & & .794 & & \\
\hline $\begin{array}{l}\text { Co-workers are currently sharing } \\
\text { knowledge with me }\end{array}$ & & & .774 & & \\
\hline $\begin{array}{l}\text { People who influence my behaviour think } \\
\text { that I should share knowledge }\end{array}$ & & & .774 & & \\
\hline $\begin{array}{l}\text { Boss is very supportive of knowledge } \\
\text { sharing }\end{array}$ & & & .772 & & \\
\hline
\end{tabular}


People in my social circle who share

knowledge have a high profile

People in my social circle who share

knowledge have more prestige than those

who do not

IT makes easy to share knowledge with

others

IT makes easy to obtain knowledge which

is relevant to me

IT makes easier to get in contact with

colleagues who have knowledge that is

important to me

Easy to access to existing communication

channels for knowledge sharing

I have access to Internet in the University

IT tools are in place for knowledge

sharing purposes

I am willing to share my resources with

colleagues using ubiquitous computing.

I intend to share knowledge and

experience with colleagues using

ubiquitous computing.

I participate in discussion groups and

workshops to share knowledge using

ubiquitous computing.

I willing to help colleagues as much as I

can when they faced problem using

ubiquitous computing

I share result with my colleagues after

attending in seminar/ meeting using

ubiquitous computing.

\begin{tabular}{lccccc}
\hline KMO & .830 & & & \\
Eigenvalue & 1.220 & 1.564 & 1.970 & 2.939 & 6.077 \\
\% of variance & 5.081 & 6.519 & 8.210 & 12.248 & 25.319 \\
\hline
\end{tabular}

Table 3 shows the reliability testing of the survey instrument. All independent and dependent variables have Cronbach Alpha values of greater than 0.7, indicating that the survey instrument is reliable (Sekaran, 2003).

Table 3. Reliability testing

\begin{tabular}{ll}
\hline Factor & Cronbach Alpha \\
\hline Individualism & .775 \\
Strategic Future Planning & .720 \\
Collaborative Organisational Culture & .774 \\
Help Facility Availability & .805 \\
Adoption of Ubiquitous Computing in Knowledge Sharing & .817 \\
\hline
\end{tabular}

As indicated in Table 4, collaborative organisational culture (standardised beta coefficient $=.362, \mathrm{p}$-value $<0.001$ ), help facility availability (standardised beta coefficient $=.300$, p-value $<0.001$ ) and strategic future planning (standardised beta coefficient $=.122$, $\mathrm{p}$-value $<0.05$ ) are important positive factors that influence local employees' adoption of ubiquitous computing devices in knowledge sharing while help facility availability (standardised beta coefficient $=.328, \mathrm{p}$-value $<0.001$ ) and collaborative organisational culture (standardised beta coefficient $=.411, \mathrm{p}$-value $<0.001)$ are important positive factors that affect foreign employees' adoption of ubiquitous 
computing devices in knowledge sharing. Individualism is not an important factor for both local and foreign employees and strategic future planning is not an important factor for foreign employees. Therefore, $\mathrm{H} 3$ and $\mathrm{H} 4$ are supported for both local and foreign employees, $\mathrm{H} 2$ is supported for local employees, and $\mathrm{H} 1$ is not supported.

Table 4. Multiple linear regression

\begin{tabular}{|c|c|c|c|c|c|c|}
\hline Category & Variable & & $\begin{array}{l}\text { Standardised } \\
\text { Coefficient }\end{array}$ & Beta & t-statistics & $\mathbf{R}^{2}$ \\
\hline \multirow[t]{7}{*}{ Local Employees } & Constant & & & & $3.404 * * *$ & .328 \\
\hline & $\begin{array}{l}\text { Collaborative } \\
\text { Culture }\end{array}$ & Organisational & .362 & & $6.429 * * *$ & \\
\hline & Help Facility & & .300 & & $5.479 * * *$ & \\
\hline & Availability & & & & & \\
\hline & Strategic Future & & .122 & & $2.151^{* *}$ & \\
\hline & Planning & & & & & \\
\hline & Individualism & & .099 & & 1.925 (ns) & \\
\hline \multirow[t]{7}{*}{ Foreign Employees } & Constant & & & & $3.394 * * *$ & .291 \\
\hline & Help Facility & & .328 & & $3.401 * * *$ & \\
\hline & Availability & & & & & \\
\hline & $\begin{array}{l}\text { Collaborative } \\
\text { Culture }\end{array}$ & Organisational & .411 & & $3.004 * * *$ & \\
\hline & Individualism & & .137 & & $.855(\mathrm{~ns})$ & \\
\hline & Strategic Future & & .142 & & .929 (ns) & \\
\hline & Planning & & & & & \\
\hline
\end{tabular}

Note. ${ }^{* * *}$ Significant at 0.001 level; $* *$ Significant at 0.05 level, ns-not significant.

\section{Discussion and Recommendation}

Both local and foreign employees perceive positive collaborative organisational culture as one of the most important factors affecting their adoption of ubiquitous computing devices in knowledge sharing. Positive organisational collaborative organisational culture seems to serve as an important determinant for frequent social interaction in private universities, which will direct affects the adoption of ubiquitous computing devices in knowledge sharing for both foreign and local employees. Trust and care are two important components of a positive collaborative organisational culture because both foreign and local employees require trust to share what they know by using ubiquitous computing devices (Zheng, 2005). Conducive collaborative organisational culture with great supervisor and co-workers engagement in sharing and learning new knowledge will improve employees' adoption of ubiquitous computing devices in knowledge sharing (Kelloway \& Barling, 2000). Therefore, strategic initiative to create a collaborative organisational culture in private universities is essential so that foreign and local employees can help each other in increasing job competencies.

In addition, the availability of help facility is another important factor that positive affects both foreign and local employees' adoption of ubiquitous computing devices in knowledge sharing. It is important to have advanced knowledge management system and technological repositories in private universities that store historical case-based solution of job-related problems faced by foreign and local employees in the organization. Appropriate taxonomy or classification system could also be implemented to help foreign and local employees to easily use the ubiquitous computing devices to search and share the case-based solution stored in the knowledge repositories.

Strategic future planning is an important factor that positively influences local employees' adoption of ubiquitous computing devices in knowledge sharing. This is because local employees are more familiar with the economic and social development of the country and can get along with colleagues and bosses more easily. They are more achievement-oriented due to their family dependencies, which leads to greater preference in utilising ubiquitous 
computing devices to acquire and share more knowledge with colleagues and supervisors in order to become success in the workplace (Witt et al., 2002). In contrast, strategic future planning is not an important determinant for foreign employees who are possibly more concerned about short-term financial rewards compared to long-term career growth and development. Therefore, competitive bonuses and rewards should be in place to encourage foreign employees to use ubiquitous computing devices to share knowledge while long-term career development should be clearly explained to local employees to motivate them to adopt ubiquitous computing devices to share knowledge with colleagues. This paper makes a significant contribution to existing literature as it is one of pioneer research in South-East Asia that establishes a positive association between strategic future planning and the adoption of ubiquitous computing devices in knowledge sharing from the perspectives of local employees in education sector.

In contrast, individualism is not an important determinant in knowledge sharing. This is because the respondents in this study mainly come from collectivist societies such as Malaysia, Myanmar, Nepal, Sri Lanka and Indonesia, which emphasizes more on collective organisational commitments towards knowledge sharing (Hofstede, 2001).

\section{Conclusion}

The findings of this study show that collaborative organisational culture and help facility availability are two important factors that positively affect adoption of ubiquitous computing devices in knowledge sharing from the perspectives of both foreign and local employees in private universities Malaysia. Strategic future planning positively influences the adoption of ubiquitous computing devices in knowledge sharing of local employees but it does not have significant impact on the adoption of ubiquitous computing devices in knowledge sharing of foreign employees. The limitation of this study is that it only focuses on studying local and foreign employees that currently work in private universities Malaysia. The research instrument used in this study can be replicated in other Asian countries to examine factors affecting the adoption of ubiquitous computing devices in knowledge sharing among foreign and local employees in those countries.

\section{References}

Ajzen, I., \& Driver, B. L. (1992). Application of the Theory of Planned Behaviour to Leisure Choice. Journal of Leisure Research, 24, 207-224.

Alavi, M., \& Leidner, D. E. (2001). Knowledge Management and Knowledge Management Systems: Conceptual Foundations and Research Issues. MIS Quarterly, 25, 107-136. http://dx.doi.org/10.2307/3250961

Alavi, M., Kayworth, T. R., \& Leidner, E. L. (2006). An empirical examination of the influence of organizational culture on knowledge management practices. Journal of Management Information Systems, 22, 191-224. http://dx.doi.org/10.2753/MIS0742-1222220307

Bates, K. A., Amundson, S. D., Schroeder, R. G., \& Morris. (1995). The Crucial Interrelationship between Manufacturing Strategy and Organisational Culture. Management Science, 41, 1565-1580. http://dx.doi.org/10.1287/mnsc.41.10.1565

Bhagat, R. S., Paula D. H., \& Harry C. T. (2002). Cultural variations in the cross-border transfer of organizational knowledge: an integrative framework. Academy of Management Review, 27, 204-221.

Cabrera, A., \& Cabrera, E. F. (2002). Knowledge-Sharing Dilemmas. Organization Studies, 23, 687-710. http://dx.doi.org/10.1177/0170840602235001

Camarinha-Matos, L. M., Afsarmanesh, H., \& Ollus, M. (2005). Virtual Organizations-Systems and Practices. Boston: Springer. http://dx.doi.org/10.1007/b102339

Cheng, N. (2009). Knowledge Sharing and Knowledge Broker of Organization (pp. 195-198). Paper presented in 2nd International Conference on Future Information Technology and Management Engineering.

Chiou, C. K., Tseng, C. R., Hwang, G. J., \& Heller, S. (2010). An adaptive navigation support system for conducting context aware ubiquitous learning in museums. Computers \& Education, 55(2), 834-845. http://dx.doi.org/10.1016/j.compedu.2010.03.015

Clearly, T., \& Zimmerman, B. (2001). Self-Regulation Differences during Athletic Practice by Experts, Non-Experts and Novices. Journal of Applied Sport Psychology, 13, 185-206. http://dx.doi.org/10.1080/104132001753149883

Coukos-Semmel, E. (2003). Knowledge Management in Research University: Process and Strategies. Paper presented in American Educational Research Association 2003 Annual Meeting, Chicago Iilinois.

Dignum, V., \& Dignum, F. (2003). Knowledge Market: Agent-Mediated Knowledge Sharing (pp. 168-179). 
Paper presented in International Central \& Eastern European Conference on Multi-Agent Systems 2003-CEEMAS, Czech Republic.

Finestone, N., \& Snyman, R. (2005). Corporate South Africa: Making Multicultural Knowledge Sharing Work. Journal of Knowledge Management, 9, 128-141. http://dx.doi.org/10.1108/13673270510602827

Flaherty, J., \& Perk, D. J. (2000). A Loaded Company Kitchen, the Globe and Mail (Toronto).

Gupta, A. K., \& Govindarajan, V. (2000). Knowledge Flows within Multinational Corporations. Strategic Management Journal, 473-496. http://dx.doi.org/10.1002/(SICI)1097-0266(200004)21:4<473::AID-SMJ84>3.0.CO;2-I

Hair, J. F., Black, W. C., Babin, B. J., \& Anderson, R. E. (2010). Multivariate Data Analysis-A Global Perspective (7th ed.). Pearson Prentice Hall, New Jersey.

Hofstede, G. (2001). Culture's Consequences (2nd ed.). Thousand Oaks, CA: Sage Publications.

Hsieh, S. W., Jang, Y. R., Hwang, G. J., \& Chen, N. S. (2011). Effects of teaching and learning styles on students' reflection levels for ubiquitous learning. Computers and Education, 57, 1194-1201. http://dx.doi.org/10.1016/j.compedu.2011.01.004

Huang, J. J. S., Yang, S. J. H., Huang, Y. M., \& Hsiao, I. Y. T. (2010). Social Learning Networks: Build Mobile Learning Networks Based on Collaborative Services. Educational Technology and Society, 13, 78-92.

Kelloway, E. K., \& Barling, J. (2000). Knowledge Work as Organisational Behaviour. International Journal of Management Reviews, 2, 287-304. http://dx.doi.org/10.1111/1468-2370.00042

Kitsantas, A., \& Zimmerman, B. (2002). Comparing Self-Regulatory Processes among Novice, Non-Expert and Expert Volleyball Players: A Microanalytic Study. Journal of Applied Sport Psychology, 14, 91-105. http://dx.doi.org/10.1080/10413200252907761

Kulkarni, U. R., Ravindran, S., \& Freeze, R. (2007). A knowledge management success model: Theoretical development and empirical validation. Journal of Management Information Systems, 23, 309-347. http://dx.doi.org/10.2753/MIS0742-1222230311

Liu, C., Marchewka, J., Lu, J., \& Yu, C. (2005). Beyond Concern: A Privacy-Trust-Behavioural Intention Model of Electronic Commerce. Information and Management, 41, 289-304. http://dx.doi.org/10.1016/j.im.2004.01.003

Liu, T. Y. (2009). A context-aware ubiquitous learning environment for language listening and speaking. Journal of Computer Assisted Learning, 25, 515-527. http://dx.doi.org/10.1111/j.1365-2729.2009.00329.x

Locke, E., \& Latham, G. (2002). Building a Practically Useful Theory of Goal Setting and Task Motivation: A 35-year Odyssey. American Psychologist, 57, 705-717. http://dx.doi.org/10.1037/0003-066X.57.9.705

Lopez, S. P., Peon, J. M. M., \& Ordas, C. J. V. (2004). Managing knowledge: the link between culture and organizational learning. Journal of Knowledge Management, 8, 93-104. http://dx.doi.org/10.1108/13673270410567657

Montana, J. C. (2000). The Legal System and Knowledge Management. Information Management Journal, 34, $54-57$.

Multisilta, J., \& Milrad, M. (2009). Sharing Experiences with Social Mobile Media. Paper presented at the Proceedings of the 11th International Conference on Human-Computer Interaction with Mobile Devices and Services (Mobile HCI09), September 15th-18th, Bonn, Germany.

Mustapha, R., \& Abdullah, A. (2005). Malaysia Transition towards a Knowledge-Based Economy. Journal of Technology Studies, 51-61.

Nahapiet, J., \& Ghoshal, S. (1998). Social Capital, Intellectual Capital, and the Organisational Advantage. Academy of Management Review, 23, 242-266.

Nijite, D., \& Parsa, H. G. (2005). Structural Equation Modelling of Factors That Influence Consumer Internet Purchase Intentions of Services. Journal of Services Research, 5, 43-59.

Nonaka, I., \& Takeuchi, H. (1995). Knowledge-Creating Company. New York: Oxford University Press.

Petrides, A. L., \& Nodine, R. T. (2003). Knowledge Management in Education: Defining the Landscape. The Institution for the Study of Knowledge Management in Education Press, USA.

Reige, A. (2005). Three-dozen Knowledge-Sharing Barriers Managers Must Consider. Journal of Knowledge 
Management, 9, 18-35. http://dx.doi.org/10.1108/13673270510602746

Sekaran, U. (2003). Research Methods for Business: A Skill Building Approach (4th ed.). New Jersey: John Wiley \& Sons, Inc.

Szulanski, G. (1996). Exploring Internal Stickiness: Impediments to the Transfer of Best Practice within the Firm. Strategic Management Journal, 17, 27-43. http://dx.doi.org/10.1002/smj.4250171105

Taylor, S., \& Todd, P. A. (1995). Understanding Information Technology Usage: A Test of Competing Models. Information Systems Research, 6, 144-176. http://dx.doi.org/10.1287/isre.6.2.144

Triandis, H. C. (1998). Vertical and Horizontal Individualism and Collectivism: Theory and Research implications for International Comparative Management. Advances in International Comparative Management, 12, 7-35.

Voel, S. C., \& Han, C. (2005). Managing Knowledge Sharing in China: the Case of Siemens Share Net. Journal of Knowledge Management, 9, 51-63. http://dx.doi.org/10.1108/13673270510602764

Wagner, J. A. (1995). Studies of Individualism-Individualism: Effects on Cooperation. Academy of Management Journal, 38, 152-172. http://dx.doi.org/10.2307/256731

Weiser, M. (1991). The Computer for the 21st Century. Scientific American, 265, 66-75. http://dx.doi.org/10.1038/scientificamerican0991-94

Witt, L. A., Burke, L. A., Barrick, M. R., \& Mount, M. K. (2002). The Interactive Effects of Conscientiousness and Agreeableness on Job Performance. Journal of Applied Psychology, 87, 164-169. http://dx.doi.org/10.1037/0021-9010.87.1.164

Yang, X. H. (2008). Improving Teachers' Knowledge Management with Blog Platform (pp. 73-77). Paper presented in 4th International Workshop on Education Technology and Training \& 2008 International Workshop on Geosciences' and Remote Sensing.

Zheng, W. (2005). An integrative literature review of organisational cultural factors that facilitate knowledge management: Implications for HRD (pp. 497-504). Paper presented at Proceedings of Academy of Human Help facility Development, Colorado.

Zimmerman, B., \& Kitsantas, A. (1999). Acquiring writing revision skill: Shifting from process to outcome self-regulatory goals. Journal of Educational Psychology, 9, 1-10.

\section{Copyrights}

Copyright for this article is retained by the author(s), with first publication rights granted to the journal.

This is an open-access article distributed under the terms and conditions of the Creative Commons Attribution license (http://creativecommons.org/licenses/by/3.0/). 